\title{
6 Some Aspects of Life in Algeria
}

\subsection{Caravansaries - The Desert - Laghouat}

The beliefs of primitive beings awaken a burning curiosity among the civilized people who build on hypotheses. As soon as they disembark in Algeria, Europeans dream of knowing this beautiful, mysterious, and magical country; however, they would like to visit it as they have visited France and Italy, that is, in comfort. They take the railroad to Oran, Constantine; some push as far as Biskra, still by rail; but when it becomes necessary, for good reason, to leave this mode of transportation common in civilized countries, they hesitate and finally give up traveling through the petit désert, ${ }^{96}$ instead of climbing into one of the old rattletraps where trip organizers pack their customers.

The stagecoach is already full of baskets, bundles, bassinets, and their Arab owners when the Europeans pile in, unable to move at all, not one foot, for hours and hours. This torture, being squeezed and forced to the utmost immobility, hurts the body and shatters the nerves.

In the immense solitude of endless horizons and frightening silence, one does not see a bird fly nor meets any human, animal or tree; above one's head are the sparkling blue sky and the burning sun and under one's eyes sand or rock. Yet desert inns, called caravansaries, have been created here, at intervals, to ensure the relay of horses and the needs of voyagers. They cannot be seen from afar, for they seem to hide. They consist of four buildings, sometimes fortified, with a large courtyard in the middle of which is a fountain shaded with greenery. Low walls surround the even lower buildings.

In the evening, stagecoaches full of voyagers arrive from every side, as do caravans and conveyers, long lines of camels loaded with merchandise and precious products, horsemen of different races and costumes. The desert inns accept all nations and hear all languages; they are the tower of Babel.

An old native man, sitting at the caravansary's entrance, graciously welcomes everyone, the poor fellahs as well as the rich conveyers from distant regions. The owners of caravansaries are watched and inspected by the authorities; the buildings and the meals are taxed. Perhaps that explains why they serve thirty persons a dinner for three. Their food supplies are not expensive though; we have witnessed the coachman haggle and buy for them one sheep out of a shepherd's immense flock for one franc and fifty centimes. But what is consumed outside of the table d'hôte escapes the fixed rate and, as a result, the rapacious innkeepers demand a high price; but in the desert hunger and thirst are too violent for negotiations.

96 Small desert, so as not to be confused with the Sahara.

(cc)BY-NC-ND $(C) 2014$ Hubertine Auclert

This work is licensed under the Creative Commons Attribution-NonCommercial-NoDerivs 3.0 License. 
Well before one reaches the Rocher-de-Sel, ${ }^{97}$ the ground is sprinkled with white and sparkling matter. There is salt on the banks of brooks, streams, and rivers. Finally the eyes are dazzled by this fairy landscape, a mountain of salt turned gold and silver, draped in the most pleasant colors by the sun. This rock of salt fills voyagers with wonder, appearing to them like a block of diamonds and precious stones.

After a succession of overlapping basins that remind the traveler of lost lakes and seas, come hillocks of pink, lilac, gold, and silver dust whirled by the wind, filling the air with a music enchanting for the ears. This phenomenon of the sonorous sands simulates both the hiss of the waves and the sound of the drum.

One can go for miles and miles without seeing a man, spend a half-day without seeing a bird. Frightening solitude, gloomy silence, such is the petit désert that travelers have to cross, burning by day, freezing at night. In these immense spaces the air is extremely healthy and invigorating. One would be ill elsewhere if subjected to the fatigue, sleep, and food deprivations one has to endure there. But despite all the sufferings, one feels an increased vital energy. Why hasn't a daring doctor established a sanatorium for anemic people in the petit désert?

The stagecoach having been attacked during the previous trip, a small troupe of armed men escorted us in the dangerous passage; from one relay to another, spahis ${ }^{98}$ galloped near the door, their brilliant uniforms alleviating the monotony of the landscape and their joyous jeers the desert's terrifying silence. One of them was kidnapping a Mauresque; in order to throw her husband and Arab pursuers off the track, he had dressed her up in European attire; this made her ungraceful without hiding her origin written over her face and her hands by tattoos. This woman, as good a mother as she was an unfaithful wife, had refused to be separated from her darling little three-year-old whom she devoured with kisses. Needless to say, all the voyagers were interested in the lovers. We poor humans know so well that the only good thing in this sad life is love that our hearts instinctively go out to those who suffer for it or enjoy it! We soon came under real rifle fire: it was not thieves who appeared suddenly but the outraged husband who was demanding his property.

To the sound of the trumpet the stagecoach triumphantly entered Laghouat. Everyone was in the street to look at it, and then followed it to where it stopped. The arrival of a stagecoach is an important event; doesn't it bring the mail in its belly, that is, news from Algiers and from metropolitan France?

Laghouat is a strange place where nothing resembles anything seen elsewhere. The women wear a theatrical costume; brocade or rags, they all wear this antique peplum with elegance. In the morning, the inhabitants are awakened by fife-players, shepherds who take to the fields the natives' huge herds of goats and sheep; these animals wear, suspended from their necks, small bells that chime gaily. Then come

97 Rock of Salt.

98 Members of native Algerian cavalry in French service. 
the Algerian infantrymen with their picturesque uniforms and their musettes, which in these wild landscapes play tunes one has never heard.

It is surprising to find a desert outpost of fewer than four thousand residents to be so nice. The streets are wide; the lined-up red brick houses all have arcades; gardens are everywhere overflowing with greenery and, were it not for the blocks of Arab dwellings built with sun-dried earth, without windows, without outside light, one could believe oneself in a coastal town. The mosque, situated on a hill, is prettily adorned with green earthenware.

The day after our arrival, we were handed a cherry tree branch heavy with fruit. Yes, European trees grow there as well as palm trees, and Laghouat is surrounded by vegetable gardens and orchards. When digging the ground one finds no sand, no rock, no stone, but black humus at a depth of more than one meter; thus everything grows vigorously: vegetables, flowers, and fruit. It is true that in that burning hot country humidity is carefully maintained around the plants. Watering is officially administered on a stated day and hour when a stream is cleverly diverted from the M'zi.

One day, in our garden, I saw an Arab who had climbed to the top of a palm tree; he was singing at the top of his lungs. Intrigued, I asked around and was told that the singer was in the process of fertilizing the female palm trees by placing in their blossoms pollen from the male palm trees. Once the act was accomplished, the operator was given a coin.

The exuberance of life manifested in the oasis of Laghouat has a few disagreeable drawbacks for the inhabitants. Not only do plants grow and multiply rapidly, but so do insects and so do reptiles. It is not rare, when getting up in the morning and putting on your slippers, to feel a cold and soft obstacle moving under your foot. It is a toad.

Mice build nests in your bed's box springs, which does not make for a good night's sleep. At night, when you are reading your newspaper, they climb two by two on your shoulder, looking at you with curiosity and twitching their tails. As for snakes, they are so numerous that they unceremoniously enter your house through the window when the door is closed. And let's not forget the lice found daily, despite the most meticulous cleanliness, in your clothes and your bed.

Despite these small unpleasant occurrences, Laghouat cannot be forgotten; once seen, one dreams of seeing it again. Will it be as attractive when it becomes possible, thanks to the rail road, to visit it more easily? Yes, because we will want to look again at the stars, which in Laghouat are as luminous as suns, and breathe in the healthy sand-sea breeze so much purer and invigorating than that of the oceans.

\subsection{Locusts}

Along with its lice and snakes, radiant Algeria harbors destructive locusts. On the hot days of July, when Parisians in the Bois de Boulogne enjoy catching the pretty green or grey grasshoppers that enliven nature and blend into its harmony, do they know 
that one day away from France, bigger and more colorfully arrayed grasshoppers than those under their eyes are a scourge, a calamity fought at times by the efforts of all of Algeria.

When a famine pushes them, these locusts of the desert act exactly like famished people who, under the pretext of war, flee to their neighbors to recover. They form myriads of legions that swoop down upon luxuriant Algeria and devour all vegetation. But that is the least of it: these grasshoppers are so numerous that they become clouds, block the light of the African sun, stop the movement of cars and trains, and lay, where they stop, eighty to a hundred eggs each, which once they hatch become these voracious crickets that clean the ground better than fires. It is said that "when there is no grass they eat wood, when there is no wood they eat stone!"

Of course, the inhabitants chase these destructive creatures as best they can. During one of the latest invasions, a mayor hired many Arabs to kill the crickets on his land of Belkacem. As he was not paying them, the Arabs worked for three days, then refused to let their own harvests be devoured any longer while they spent their time protecting those of the mayor without pay. The municipal magistrate took down the particulars of this offense and the juge de paix of Dellys condemned seventy-two of them to five days in prison and a fine of fifteen francs. The governor, to whom this unjust sentence was appealed, refused to reverse it, thereby confirming the Arabs' free and mandatory subjection to the French Algerian authorities.

The locusts fear only storks in battle formation, pecking into their living, flying wall. Unperturbed by noise, smoke, and stretched sheets (a Cypriot device), the terrible acridians proved that they mock these obstacles as they swooped down on Algiers. A few companies of scouts appeared (males first), then came not just companies of locusts, but the ceaseless swirl of an army of golden scarabs sparkling under the sun in the blue sky, resembling in number and speed - but not in color - the swirl of snowflakes.

In their breathtaking flight these living golden flakes advance in layers: some touch the clouds, others graze the ground. After their passage terraces and balconies are stained with the proofs of their digestion. The creatures do not turn up their noses at flowers and greenery; great numbers of them fall into chimneys.

This invasion of locusts amuses the inhabitants of Algiers, but is the despair of colonists and natives. Announcing to all the coming of a famine, it offers a strange spectacle: drinking and eating are forgotten in favor of watching the flights; children and adults grasp passing insects and laughingly throw them to each other; this calamity looks like a party. Some make grasshopper rosaries, some put a few under a glass; everyone is eager to try a little experiment with having eggs laid and crickets hatched in a bowl. I did as everyone else; upon seeing this, our Arab asked me, "You want to eat some?" I did not dare to taste them, for our prejudices about anything relating to food are very strong. I have been assured that their thighs taste somewhat like crayfish, and a chemist who analyzed them certifies that they are eleven times more nutritious than beef. 
In southern Africa, these salted, dried insects are the basic food staple of many tribes; some grind them into a powder for making bread. Nomads eat them raw and cooked; for them they are manna from heaven. In the Koran, Mohammed authorized the use of locusts, but I do not believe many residents of North Africa will take it into their heads to eat them; however, it might be sensible to preserve them to be eaten during a drought, when the fertile Algerian plains will be transformed into an immense swarming yellow sea.

Without a break, winged battalions after battalions form huge clouds rising from the south to the north, poisoning cisterns and streams with the corpses of their laggards.

In the presence of this catastrophe one must wonder why men, who are not able to stop either destruction or death, are alone at the helm. If women had a place there, can we be sure that they wouldn't have found a way - thanks to their foresight and intuition - to paralyze the action of the locusts?

The poor - men, women and children - pick up the locusts, which are then bought by the Algerian municipality for one franc a bag of twenty-seven kilos. The people do not respond in great numbers to the feeble appeal to fight this plague, even though all of Algeria should enthusiastically rush out to fight this monstrous invasion. The clever and the protected obtain large compensation from the accounts created to organize help and defense. But what about the small settlers? What about the natives? Who thinks of them? Will they always be condemned to die of hunger as they did in 1867 and poison the air with their corpses left unburied in their devastated fields?

Let us not forget that in taking possession of Africa the French have taken upon themselves, at the same time as power, responsibility for people and things. They have charge of bodies and charge of land. The Arabs expect from the French occupiers - who, despite their science and their civilization, have been unable to foresee or prevent the locust invasion - the possibility of subsisting after the insects have devoured their harvests.

Everyone agrees that our vast African territory should be populated and everyone agrees that this is not so easy. Well! Let us start then by preventing the Arabs who inhabit this territory from dying of hunger. Only our solicitude for them can protect the results of human efforts in French Africa.

\subsection{My Gazelle Yzette}

Traveling toward the south of Algeria, along barely traced paths, in one of those rattling primitive coaches, one often meets gazelles in groups of seven or eight. Seeing them flee hardly touching the ground, like birds, the most blase travelers let out a shout of admiration; however fleeting their apparition, everyone is seduced by their irresistible charm and entertains the hope of owning one or two and bringing them back to Algiers, where they would live just long enough to be adored, then leave their 
adoptive parents inconsolable. That is probably the reason why they are called "bêtes à chagrin." 99

However, isn't it for the gazelles that have been created on the fourth floor of so many houses in Algiers the terraces we see, true hanging gardens with bowers fragrant with the scent of honeysuckle? But what are a few square meters for creatures used to leaping in the immensity of the desert? The people who sequester them there are soon punished for this crime, seeing them die at the peak of their charm, kindness, and familiarity.

During a stay in the southern Oran region, we too were captivated by these sirens of the desert, and we raised three gazelles: Mina, whose size forced us to leave her in the care of friends, and Ali and Yzette, a delightful couple we brought to Algiers with the intention of bringing them to France.

Ali, our little male gazelle who smiled showing his teeth, immediately became friendly and affectionate. He would stand erect on his hind legs, leaning his front legs on my belt, articulating sounds similar to a child's lisp, so it was said that I had a talking gazelle.

Yzette was the perfection of her race in beauty and intelligence. When she was brought to me, very young, her coat was silk, her legs matchsticks, and her eyes immense, radiant! I had never seen anything so beautiful. Filled with wonder, I took her in my arms from which she escaped, or rather flew away like a bird. My admiration for this little jewel of the desert drove me constantly to pick her up, press her to my breast and cover her with kisses. Each time she would escape with the same impetuosity, hurting her thin legs, giving me black-and-blues and tearing my dress from top to bottom.

It was Yzette who sucked most of the milk from the white goat that was also Ali and Mina's nurse. When we took our gazelles to graze on the flowers - flowers of our French gardens that grow wild on the Algerian plateaus - I held the ribbon attached to Yzette's collar; at the same time as her mouth, my hand picked her favorite plants to offer them to her.

The nervousness of this little electric being cannot be described: as soon as she saw an animal or a person, she ran, terrified. With the prodigious strength stored in her tiny body she pulled me home, where she arrived out of breath, sweaty, her little grey tongue hanging out of her mouth.

It is very difficult to transport gazelles from one country to another without hurting them. To take them to Algiers we put Yzette and Ali in a basket with a well padded bottom and a top covered with a veil to protect their pretty heads. During the trip we would neglect to eat in the stagecoach post-houses, we would forget to register our luggage at railroad stations, so concerned were we with them! In Relizane, despite our pleading, they were put in with the freight; then each time the train stopped for a

99 More trouble than it's worth. 
few minutes, I would run to their car, kneel in front of their basket, and drop grapes into their mouths. When we arrived in Algiers, Yzette and Ali, exhausted by three days of immobility, refused to eat for twenty-four hours.

We were allowed, after much pleading, to keep them in our hotel, in a living room adjoining our bedroom. These pretty creatures, full of vigor, were not always good. One night, our neighbor, a priest, heard their stamping, groans, and squeals. Frightened, he went down to the office and said to the owner, "Madame, there is someone very ill in room number 6; there is a man who won't live through the night, I believe he is dying; when I heard him hiccough, struggle, fight death, I got up and I have come to ask you to offer him the assistance of our holy religion."

The boys who were called affirmed there was no one ill in the hotel, that the priest had had a bad dream or was the victim of a hallucination. The next night, same uproar; the priest again came to the office and said to the owner, "I was wrong, it is not a sick man, it is an epileptic; he bumps into everything in his convulsions, he complains, he shouts, he screams! It is awful!" And the priest offered to help the body as he had offered, the night before, to help the soul. Even though he spent nights holding his breath, his ear against the wall, he left the hotel without suspecting that it was two innocent gazelles that caused all the commotion. However, fearing more complaints, we boarded our gazelles. Every morning I would bring greens to them; it was a great joy for us to see each other again; they wanted to follow me when I left."

As soon as we rented an apartment with a terrace for them, we had them brought to us and they really became part of our lives. During meals, Yzette and Ali, one gentler than the other, would approach the table, making a little squeal resembling "eh-eh? Don't you give us anything?" And their pretty muzzles would pick the fruit off our plates. They liked all raw or cooked vegetables. Ali even enthusiastically devoured fish and meat. Both were very fond of things of the earth. After our meal came theirs. They would eat artichokes, cabbages, carrots, branches of vine, and honeysuckle, geranium flowers, and barley morning and evening. The bag of barley had a magical effect on Yzette and Ali: as soon as they saw it, joy would light up their big eyes; they would put their small feet on ours to bring their sweet muzzles closer to it. We would fill our hands with barley and how they ate it! Sometimes their two heads were in the same hand, I was going to say in the same plate. When the barley was gone, they wanted to play with us as they would have done with friendly gazelles.

To make them lie down, we would stretch a carpet in front of them, but that was for Yzette the signal of playtime; she would step on it with impatient feet, she would lower her horns to the ground in front of one of us, then brusquely lifting them up, she would forcefully inhale and start a series of leaps and graceful movements that delighted us and made us drop our pen or our newspaper.

If one pursued Yzette she in turn pursued, played hide-and-seek with more skill than her partner. She would dance, turn, jump way up on four legs, making this nervous "squeaky" noise which, they say, is a sign of the greatest pleasure for gazelles. When we found them destroying the curtains or the furniture and slapped them, Ali 
would come and lick the hand that had hit him; on the contrary Yzette pouted, stayed aloof, and one had to show her a lot of kindness to make up with her and regain her good graces.

In the presence of a dog, Ali and Yzette would take a combative stance: hocks arched, head bent, they presented their little horns. In this defensive posture they brought to mind their desert siblings, who, in time of bad drought, unite in herds of ten to twenty thousand and look for a cooler climate. Pursued by lions and panthers, they fight strength with numbers, march in tight columns, form circles, and offer their ferocious assailants a wall of sharp horns.

Yzette and Ali, who seemed happy only when they were with us, were at once our joy and our treasure; we showed them with pride to anyone who entered our home. Visitors compared their beautiful eyes, so vivacious and yet so gentle, to big black diamonds.

Alas! Good things soon come to an end; a cruel fate snatched our gazelles. Ali died first. Yzette really grieved for her playmate; for a week she was in despair, did not come to us, refused food, and cried like a human. We showered her with love. We had the idea of letting her roam freely on the terrace and in the apartment. This semiliberty consoled her. After fearing to see her die of sorrow, we had the joy to see her play again and still grow in strength and beauty.

Ali's death had triggered in Yzette an extraordinary sensitivity. Being alone was unbearable for her; she followed me in the apartment, lay down at my feet when I sat and, at the time of my siesta, stretched on the carpet next to my bed. It was no small matter to leave this sensitive little creature: long before leaving the house, I would do my utmost to distract her, I played with her, I showered her with flowers and barley, all in vain; the dear little animal ran terrified, raised herself on the tips of her feet to be sure that I was no longer there, and oh, how she moaned! Her sorrow persisted long after I came back. How I avoided being absent!

Yzette would stamp her feet when I brushed her, but when I smoothed her coat with a comb, she licked my hands. Ah! What skin! What a superb coat covered her elegant curves! Never a louse, never a flee; a speck of dust falling on her was speedily removed with a fast kick of her little foot.

Gazelles smell of the musk they produce naturally. The Arab nomad has no other perfume than the gazelles' musky droppings.

Yzette's eyes sparkled with intelligence like those of the most talented human being. She was for us a companion who understood and felt everything that moved us. Gazelles are true companions for those who have adopted them. Yzette shared our joys and our sadness, she identified with our moods.

When we called her by one of her names, Yzette, Zizie, she would answer, "eh? eh?" When, not seeing her and looking for her we would find her lying down in an adorable posture, her legs stretched out, we would call each other to come and admire her. "Oh," we said, "How pretty she is!" and we would spend several minutes in rapture before her. 
One morning, I was awakened by our little friend's halting respiration; her throat was constricted. We immediately called the veterinarian who wrote a prescription. But remedies did not cure Yzette, she lost her strength, she began to bump into the furniture. Whereas when she was little she would bleat and fight me when I took her in my arms, now that she was tall and strong she would let me carry her without resisting. When she fainted, our kisses would bring her back to life; then I would bring her flowers which she ate avidly.

One night she had terrible convulsions, raspy and guttural shrieks came out of her throat; she opened her mouth wide, her eyes turned and went dark. Yzette was dead! The disease had not marked her handsome body; even in death she was radiant. Seeing her so beautiful, even the taxidermist was in awe.

More than once I saw my little gazelle Yzette in a dream, stretching out her two pretty paws toward my neck, standing up and leaning against me, happily eating grass and flowers.

I gaze at her body placed on a cushion that simulates an altar. This bewitching little creature evokes for me the sea of golden sand, the music of the wind in the desert's immensity. In this misty and cold Paris, it gives me the illusion of the wonderful warmth of sunny Africa. 